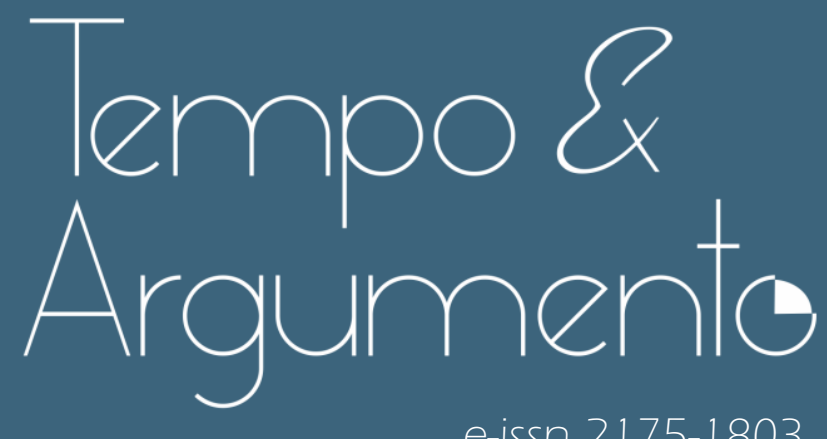

e-issn 2175-1803

\title{
Conflitos afro-asiáticos "quentes" da Guerra Fria: da revolução à guerra (anos 1970 e 1980)
}

$\diamond$ Paulo Gilberto Fagundes Visentini

Doutor em História Econômica pela Universidade de São Paulo (USP).

Professor da Universidade Federal do Rio Grande do Sul (UFRGS).

Porto Alegre, RS - BRASIL

lattes.cnpq.br/2013094835500963

paulovi@ufrgs.br

(i) orcid.org/0000-0001-5654-8874

Para citar este artigo:

VISENTINI, Paulo Gilberto Fagundes. Conflitos afro-asiáticos "quentes" da

Guerra Fria: da revolução à guerra (anos 1970 e 1980). Tempo e Argumento,

Florianópolis, v. 13, n. 32, e0103, jan./abr. 2021.

doi http://dx.doi.org/10.5965/2175180313322021e0103

Recebido: $30 / 10 / 2020$

Aprovado: $11 / 03 / 2021$ 


\title{
Conflitos afro-asiáticos "quentes" da Guerra Fria: da revolução à guerra (anos 1970 e 1980)
}

\begin{abstract}
Resumo
O Século XX foi marcado por grandes conflitos armados, sendo duas Guerras Mundiais ("quentes") e uma Guerra Fria, associada a confrontos militares e Revoluções no Sul. Durante a década de 1970, ocorreram mais de uma dúzia de Revoluções no Terceiro Mundo/ Sul Geopolítico, da Nicarágua ao Vietnã, de Angola ao Afeganistão. A maioria delas se transformou em Guerras convencionais, isto é, conflitos militares internacionais, que perduraram durante os anos 1980. O presente artigo analisa os casos de Angola e Etiópia, na África; do Irã e do Afeganistão, no Oriente Médio; e do Vietnã e Kampuchea/Camboja no sudeste da Ásia. Libertação Nacional, Revolução Social e Guerras geopolíticas internacionais estiveram intimamente associadas nesses conflitos transformadores, que marcaram a História Mundial Contemporânea.
\end{abstract}

Palavras-chave: Revoluções. Guerras. África. Ásia.

\section{The "hot" afro-asian conflicts of the Cold War: From Revolution to War (1970's and 1980's Years)}

\begin{abstract}
The 20th century was characterized by major armed conflicts, two ("hot") World Wars and one Cold War, linked to military confrontations and revolutions in the South. During the 1970's more than a dozen Revolutions in the Third World/Geopolitical South took place, from Nicaragua to Vietnam, and from Angola to Afghanistan. Most of them turned into conventional wars, namely, international military clashes, that lasted until the 1980s. The present article analyses the following cases: in Africa, Angola and Ethiopia, in the Middle East, Iran and Afghanistan, and, in Southeast Asia, Vietnam and Kampuchea/Cambodia. National liberation, social revolution and international geopolitical wars were closely intertwined in these changing conflicts, that branded Contemporary World History.
\end{abstract}

Keywords: Revolutions. Wars. Africa. Asia.

\section{Introdução}

Os conflitos armados, sejam internos (revoluções, guerras civis e golpes de Estado) ou externos (guerras convencionais interestatais), constituem fenômenos recorrentes em todas as épocas históricas. Entretanto, nem sempre são vistos como conflitos sociais, em que revoluções provocam guerras ou 
guerras propiciam condições para a eclosão de uma revolução (DEUTSCHER, 1991). O encerramento da Guerra Fria, com seu "Fim da História" de Fukuyama, retirou da agenda de pesquisa e do debate político a onda revolucionária dos anos de 1970, enfocando separadamente apenas as guerras que a ela se seguiram. Neste contexto, o foco do presente artigo será a análise do impacto internacional de duas Revoluções Africanas (Angola e Etiópia), duas do mundo islâmico/Arco das Crises (Irã e Afeganistão) e duas da Ásia/Indochina (Vietnã e Camboja). Todas elas ocorreram entre 1974 e 1979 e seus efeitos foram intensos até o final da Guerra Fria (e continuam, embora com outra significação).

Halliday (1983; 1989) observa que durante esse período, em pouco mais de uma década, ocorreram quatorze revoluções no Terceiro Mundo. Elas tiveram expressivo impacto regional, gerando tendências e contra-tendências, bem como violentos conflitos internacionalizados e guerras civis. Devido ao equilíbrio de poder então existente e às transformações por que passava a economia mundial, elas acabaram afetando o sistema internacional. No final da década de 1970, encerrou-se a Coexistência Pacífica e teve início uma Segunda (ou Nova) Guerra Fria nos anos 1980. Tudo isso contribuiu para uma mudança profunda das relações internacionais, que teve como desfecho a implosão do campo soviético e, para o desequilíbrio de poder que se seguiu e ainda desestabiliza o sistema mundial (FONTAINE, 1995).

Academicamente, as Relações Internacionais iniciaram como estudo da guerra como ato agressivo racional e deliberado, e não como a internacionalização de um conflito social. A própria Carta da ONU se preocupa com a ordem mundial como se ela fosse separada da situação interna dos Estados. Na mesma linha, a Ciência Política anglo-americana considera a Revolução como uma quebra de processos regulares. Até a publicação da obra de Theda Skocpol (que de certa forma atualiza o clássico de Barrington Moore Jr “As origens sociais da ditadura e da democracia”), as Revoluções eram encaradas como fenômenos internos. Jack Goldstone (1991, apud HALLIDAY, 1999), por sua vez, enfatizou que fatores internacionais (tais como pressões econômico-fiscais e política de alianças desestabilizadoras) enfraqueciam o Estado e propiciavam condições para a eclosão de revoluções. 
Realistas e neorrealistas como Kenneth Waltz, ao não relacionarem a dimensão interna com a externa, ignoram que a maioria das alianças diplomático-militares visam impedir a eclosão de revoluções dentro de Estados membros. Certamente as Revoluções não podem escapar ao sistema previamente existente, mas elas forçam sua mudança e representam momentos de transição para uma nova realidade mundial, embora as Relações Internacionais as percebam como "colapso" (ou ruptura negativa, antissistêmica). Cabe destacar que toda a revolução tenta internacionalizar-se, da mesma forma que a contrarrevolução (que busca manter a homogeneidade sistêmica), geralmente sem sucesso. Assim, os limites da "exportação da Revolução" (ou da contrarrevolução), geram tréguas, redução da retórica ideológica e uma postura mais diplomática. Todavia, isso não significa que as revoluções tenham sido "socializadas", pois, segundo Halliday (1999, p.187), "enquanto suas ordens internas pós-revolucionárias permanecerem intactas, elas continuam a representar um desafio ao sistema de outros Estados."

Para a sociologia histórica, o “internacional” criou o Estado, e não o contrário, e no tocante aos processos revolucionários aqui estudados em sua dimensão internacional, cabe ressaltar que guerras geram revoluções e viceversa. Nos casos analisados, por exemplo, percebe-se que as revoluções dos anos 1970 levaram a guerras convencionais na periferia (com envolvimento direto ou indireto de grandes potências), para as quais a comunidade internacional não estava preparada. Além disso, no plano regional, o maior impacto não é tanto a ação deliberada, mas o exemplo, que serve de catalisador contra a ordem estabelecida. Neste sentido, as Guerras que se seguiram às referidas revoluções, constituem, igualmente, uma forma de contrarrevolução internacionalizada.

\section{Revoluções, a dimensão ausente na História das Relações Internacionais}

Para fins teóricos e metodológicos deste artigo, revolução significa uma mudança política brusca, geralmente violenta (mas nem sempre), com a derrubada de um regime e a luta pela construção de outro novo. Essa ruptura na ordem vigente busca efetuar alterações estruturais nos ordenamentos jurídico- 
político e socioeconômico. O elemento deflagrador de tal evento pode ser um levante popular, uma insurreição armada, um Golpe de Estado ou até mesmo uma transição política relativamente pacífica. Mas, para esses elementos conjunturais serem eficazes, é necessário haver condições políticas objetivas favoráveis, tanto domésticas como externas (RICHARDS, 2004).

Além das revoluções burguesas, das revoluções democrático-burguesas (com forte participação popular) e das revoluções socialistas propriamente ditas, durante a segunda metade do século XX, desenvolveram-se as revoluções democrático-populares, especialmente em países periféricos. Trata-se das revoluções de libertação nacional, das democráticas, das anti-imperialistas e das "antifeudais" do Terceiro Mundo, geralmente ligadas à descolonização e ao nacionalismo. Nelas, os elementos deflagradores foram revoltas populares, mobilizações reformistas, golpes de Estado (inclusive militares) e lutas de guerrilha como as teorizadas e promovidas por Mao Zedong, Ho Chi Minh, Amílcar Cabral, Fidel e Raúl Castro e Che Guevara, entre outros (SILVA, 2004). Nelas, havia uma aliança entre segmentos da pequena burguesia e do campesinato, além de setores do operariado.

As revoluções sempre estão relacionadas a fatores tanto internos quanto externos e, na sequência de sua concretização, necessariamente geram um impacto internacional na medida em que afetam regras internas nas quais a ordem (capitalista) internacional se baseia. "As Revoluções são eventos internacionais em suas causas e efeitos", como lembra Fred Halliday (2007, p. 148). Neste sentido, inspiram forças políticas de outros países, tanto simpatizantes como adversárias. Normalmente as revoluções dão origem a guerras externas, geralmente associadas a guerras civis internas ou são delas resultantes (SKOPCOL: 1979; SCHUTZ, SLATER: 1990).

O socialismo de orientação marxista logrou, ao longo do século XX, impulsionar um conjunto de revoluções vitoriosas em sucessivas ondas, que instituíram o primeiro sistema pós-capitalista. A primeira delas teve lugar na esteira da Primeira Guerra Mundial, com o triunfo da Revolução Russa e a construção do socialismo na URSS. A segunda, decorrente dos movimentos antifascistas e dos resultados da Segunda Guerra Mundial, afetou o Leste 
europeu, tanto através das "revoluções pelo alto" apoiadas por Moscou, que constituiriam as Democracias Populares, quanto por meio das revoluções autônomas da lugoslávia e da Albânia. É importante ressaltar que a Alemanha, a Hungria, a Tchecoslováquia e a Bulgária protagonizaram, no final da Guerra (191823), revoluções e, inclusive, breves regimes socialistas, com a esquerda sendo, posteriormente, derrotada, às vezes por intervenção externa.

A terceira, que vinha se desenvolvendo paralelamente à anterior, teve como epicentro a Revolução Chinesa, iniciada já na década de 1920, caracterizada pela questão camponesa e nacional. Após um quarto de século de guerrilhas e guerras, a nação mais populosa do planeta tornou-se um regime socialista. A Revolução Coreana e a primeira etapa da Indochinesa fazem parte dessa fase. As revoluções marxistas e regimes engendrados na primeira metade do século XX ocorreram "na periferia do centro". As potências capitalistas industriais que dominavam o centro do sistema entraram em conflito aberto (corrida imperialista, Primeira e Segunda Guerra Mundiais), enquanto lutavam por redefinir o sistema mundial e, dentro dele, a posição hegemônica. Assim, foi possível a vitória de duas revoluções e regimes estruturantes de nova realidade mundial, a soviética e a chinesa. Elas se encontravam na periferia do espaço geopolítico afetado pela gigantesca confrontação e transformação, isto é, na periferia do núcleo central.

Finalmente, na quarta e última, o movimento de descolonização e o nacionalismo do Terceiro Mundo protagonizaram o triunfo de diversas revoluções de orientação socialista, como a cubana, a nicaraguense, a vietnamita, a afegã, a sul-iemenita e as africanas dos anos 1970. Elas ocorreram na segunda metade do século XX "no centro da periferia", isto é, na região geopolítica meridional do planeta ainda não industrializada, onde ocorria a expansão do desenvolvimento desigual e combinado do capitalismo (DAVIS, 1985; WESTAD, 2007).

Dentre as referidas, apesar dos limitados recursos, duas acabaram se tornando paradigmáticas e tendo efeitos sistêmicos globais, a cubana e a vietnamita. Evidentemente, elas estiveram ligadas e dependeram das duas grandes revoluções fundacionais, mas desenvolveram uma dinâmica própria. O caso da Revolução Iraniana pode ser enquadrado nessa categoria, embora seu 
desdobramento tenha sido diferente como projeto pós-revolucionário. De qualquer forma, a "islamização" do processo revolucionário não anula sua base republicana, modernizadora, anti-imperialista (mas não anticapitalista) e internacionalista (HAGHIGHAT, 1985).

Revoluções africanas e seus impactos regionais

\section{A Revolução Angolana e a Guerra da África Austral}

A descolonização da África, no início dos anos 1960, deixou de fora os chamados bastiões brancos do sul do continente. Portugal, que abrigava interesses econômicos transnacionais, recusou-se a conceder a independência a Angola e a Moçambique. A África do Sul, governada pela minoria branca, controlava a Namíbia e na Rodésia (atual Zimbábue), os colonos brancos apoiaram lan Smith na proclamação da independência em 1965, não reconhecida por Londres. A África do Sul, onde a segregação racial do apartheid estava consagrada na constituição, possuía grande força econômica, posição estratégica, poder militar e estava associada a corporações transnacionais (CHAZAN, MORTIMER, RAVENHILL, ROTCHILD: 1992; VISENTINI: 2012).

A impossibilidade dos movimentos anticoloniais em lograr a independência, um governo de maioria negra ou mesmo o direito de participação política, em decorrência da intransigência de Lisboa e das minorias brancas, provocou o desencadeamento da luta armada. O Congresso Nacional Africano (CNA) abandonou as posições moderadas após o massacre de manifestantes negros em Sharpeville (1960), aliou-se ao Partido Comunista Sul-Africano e iniciou uma guerrilha em condições dificílimas. O mesmo ocorreu com a Organização do Povo do Sudoeste Africano (SWAPO) na Namíbia, em 1966, após a África do Sul recusar-se a devolver à ONU esse território que administrava em fideicomisso (direito provisório de administração concedido pela Liga das Nações). A ZAPU e a ZANU (respectivamente União Popular e União Nacional Africana do Zimbábue), com a declaração da independência da Rodésia pelos brancos, também lançaram ações de guerrilha. 
Amilcar Cabral, ideólogo da luta armada de tendência marxista nas colônias portuguesas, lançou a guerrilha na Guiné-Bissau, enquanto diversos movimentos fundiam-se na Frente de Libertação de Moçambique (Frelimo), também iniciando a luta (CABRAL, 1980; DAVIDSON, 1979). Em Angola, após o massacre de milhares de negros, na esteira das primeiras ações armadas em 1961, várias organizações igualmente desencadearam a guerra contra os portugueses. Esses grupos aglutinaram-se, gradativamente, em três movimentos, a Frente Nacional de Libertação de Angola (FNLA), a União Nacional para Independência Total de Angola (UNITA) - correntes moderadas e pró-ocidentais de base étnica do norte e do sul, respectivamente, e o Movimento Popular para Libertação de Angola (MPLA), de tendência socialista revolucionária e base urbana e interétnica (TURNER: 1998).

A FNLA e a UNITA eram correntes moderadas e pró-Ocidentais de base étnica do Norte (bakongos) e do Sul (lunda, ambó e nganguela), respectivamente, e o MPLA de tendência marxista, de base urbana e interétnica, mas com predominância dos quimbundos e ovimbundos, da região central e litorânea. A primeira era apoiada pelo Zaire (Mobutu era cunhado de Holden Roberto), EUA e China; a segunda pela África do Sul, China e, discretamente, durante certo período, pela própria polícia política portuguesa, enquanto o terceiro movimento tinha um suporte cubano e soviético. Durante o desenvolvimento da luta armada, houve várias crises no relacionamento dos três grupos, e o reconhecimento da OUA passou da FNLA para o MPLA, quando mais tarde foi descoberta a conexão da primeira com a CIA, embora os países moderados mantivessem seu apoio a esta e à UNITA. É preciso considerar, ainda, que o potencial militar de Portugal não era apenas o de um pequeno país pobre, na medida em que se tratava de um membro da OTAN, a qual the forneceu apoio estratégico na repressão aos movimentos de libertação africanos (CHABAL, 2002; SOMERVILLE, 1989).

Apesar das dificuldades militares da guerrilha, o conflito acabou causando desgaste político-econômico e a derrubada do regime fascista de Lisboa, com um Golpe Militar que propiciou a Revolução dos Cravos em abril de 1974, na qual a esquerda se tornou dominante. O novo governo português, especialmente as tropas acantonadas em Angola, se aproximaram dos movimentos de libertação, 
sobretudo o MPLA, por afinidades políticas. Era a independência de maior impacto internacional da África Portuguesa, pois o país contava com maiores potencialidades econômicas (petróleo, ferro, diamantes e minerais estratégicos) e expressiva minoria branca. A divisão e o confronto entre os três grupos que lutavam pela independência acirraram-se quando se aproximava a data marcada para a independência (novembro de 1975). A FNLA (vinculada aos Estados Unidos) e tropas de Zaire avançaram do Norte para atacar a capital, Luanda, onde o MPLA era dominante. A invasão foi derrotada pelo MPLA com apoio de instrutores cubanos que começavam a chegar ao país'. Entretanto, no Sul, a UNITA e o exército sul-africano desencadearam um ofensiva-relâmpago contra o MPLA de Agostinho Neto. Iniciou-se então uma ponte aérea entre Havana e Luanda, com o envio de armas e vinte mil soldados. No centro do país, as tropas cubanas (boa parte dos quais descendente de ex-escravos) e do MPLA derrotaram o exército sul-africano, um dos melhores do mundo (CHALIAND, 1982).

Em Angola, o exército da África do Sul manteve a ocupação uma faixa de 100 km no sul do país, para dar proteção à guerrilha da UNITA, que Pretória apoiava com armas e dinheiro. Também visava evitar o estabelecimento de bases da SWAPO e a penetração de seus guerrilheiros na Namíbia. Os sul-africanos também sabotavam a infraestrutura angolana através da ação de comandos, inclusive nos oleodutos de Cabinda, no extremo norte do país. Até 1980, as ações eram limitadas e as tropas cubanas se preparavam para deixar o país, mas a eleição de Reagan alterou radicalmente o quadro político, com a escalada do confronto militar, através do auxílio material à UNITA e político à Pretória (SHUBIN: 2008). Os soviéticos tiveram de enviar mais armas e assessores, e os cubanos mais soldados. As forças das FAPLA (exército angolano) e cubanas tiveram de travar uma guerra convencional e de contra-insurgência nos amplos e despovoados territórios do centro-sul de Angola. Inclusive batalhas aéreas e de blindados foram travadas, com um desempenho cubano-angolano cada vez mais eficaz, mas com um elevado custo humano e econômico para a nação recém-

\footnotetext{
Dia 11 de novembro de 1975 foi proclamada a República Popular de Angola pelo MPLA, em Luanda, enquanto a FNLA e UNITA, aliadas, proclamavam a República Democrática de Angola em Huambo, no planalto central angolano. Os remanescentes da derrotada FNLA seriam, posteriormente, incorporados pela UNITA.
} 
independente. As forças cubanas totalizavam 20 mil soldados voluntários (200 mil teriam lutado em Angola), além de cooperantes civis nas áreas social, de engenharia e econômica. ${ }^{2}$

Assessores soviéticos e do leste europeu, além de ajuda econômica, tornaram Angola cada vez mais dependente dos países socialistas, embora vendesse seu petróleo (explorado no litoral) e diamantes ao Ocidente (SOMERVILLE, 1993). Aliás, o controle dos campos de diamantes, localizados no interior, era duramente disputado com a UNITA, que se financiava, parcialmente, com essa riqueza e também era apoiada pela China. Em 1988, foi travada a longa Batalha de Cuito-Cuanavale, que derrotou a ofensiva sul-africana e da UNITA, e foi bombardeada uma represa hidroelétrica na fronteira da Namíbia pelos cubanos, obrigando o regime racista a negociar a paz. O resultado foi logrado pela determinação cubana e do setor militar em Moscou, contrariando Gorbachov, que desejava ceder (GEORGE, 2005). Em 1989, em troca da retirada cubana e da participação política da UNITA em Luanda, a África do Sul retirou as suas tropas e acatou a antiga Resolução da ONU para a independência da Namíbia, com participação da SWAPO. Angola vivenciara 15 anos de lutas de guerrilha revolucionária e mais 15 de guerra convencional. Mas a paz seria precária, e em 1992 teria início nova Guerra Civil, encerrada somente em 2002, com a morte de Savimbi em combate (CHABAL, 2002).

\section{A Revolução Etíope e a Guerra do Chifre da África}

A revolução etíope derrubou um império milenar, aliado dos EUA em uma região estratégica. O que começou como um Golpe Militar, convergente com protestos populares, evoluiu para um regime socialista, Guerra Civil e confronto internacional. Mas o grande conflito que sacudiria a região tivera início na Somália, que possuía um regime instável e incompetente. Em outubro de 1969, o MajorGeneral Mohamed Siad Bare liderou um Golpe de Estado Militar, quase sem derramamento de sangue, e implantou o Conselho Revolucionário Supremo. Com maioria militar, ele incluía vários civis da intelligentsia, graduados na Itália e na

\footnotetext{
${ }^{2} \mathrm{O}$ autor realizou uma série de entrevistas com ex-combatentes cubanos das guerras de Angola e Etiópia em Havana, em maio de 2019.
} 
URSS. Formalmente o regime buscava legitimação no combate à corrupção, ao nepotismo, ao suborno, ao roubo, e, também, criticava o sistema de clãs. Muitos oficiais tinham formação no exterior, especialmente no Egito de Nasser (OTTAWAY, 1982).

Em maio de 1970, o regime nacionalizou os bancos, distribuidoras de petróleo, produtoras de energia e de açúcar (quase todas estrangeiras) e, em outubro, proclamou a adesão ao "socialismo científico". Ele precisava produzir uma alternativa crível ao regime deposto, rumo ao desenvolvimento e à soberania. Todavia, numa sociedade caracterizada pelo predomínio do analfabetismo e do nomadismo, os intelectuais tiveram que buscar um conceito equivalente, Handiwadaag (“compartilhar a riqueza”). Entre 1970 e 1978, a Somália se aproximou do campo soviético e de Cuba, recebendo assistência técnica, ajuda militar e apoio diplomático. A Somália encontrava um apoio e um modelo, enquanto a URSS encontrava um aliado geopolítico frente à Etiópia próamericana. Mas Barre nunca chegou a confrontar as petromonarquias da península arábica, da qual também recebia certo apoio financeiro ao seu miserável país. A implantação de instituições e práticas políticas e sociais socialistas marxistas-leninistas foi intensa, juntamente com a montagem de um exército moderno. Todavia, a história preparava mais uma de suas ironias (COKER, 1985).

Na Etiópia, castigada pela miséria, seca, arcaísmo sociopolítico feudal e pelas guerrilhas muçulmanas e esquerdistas na Eritreia, o regime não resistiu. O velho imperador pró-americano, Haile Selaissie, foi derrubado em 1974 por um golpe militar, quando havia grandes protestos populares urbanos e revoltas rurais. A junta militar (DERG) exprimia um populismo pouco definido, enquanto as oposições, o caos e as tendências centrífugas ameaçavam a existência do novo regime e da integridade territorial. Enquanto crescia a luta de facções dentro do grupo dirigente, ele se ligava cada vez mais ao programa das correntes de esquerda civil (que o apoiavam criticamente) e implementava uma ampla reforma agrária, mobilizava a população nos Kebeles (Comitês de Defesa da Revolução), rompia com os Estados Unidos e enfrentava os movimentos de oposição (SCHWAB, 1985). 
Em 1977, ascendeu à direção do DERG o coronel Mengistu Haile Marian, formado nos EUA, que adotou o projeto da oposição marxista civil e depurou a Junta dos Generais mais conservadores. Enquanto definia-se pelo socialismo, as rebeliões da ultraesquerda (PRPE e Meison ${ }^{3}$ ), dos separatistas ou autonomistas e dos contrarrevolucionários conservadores agitavam quase todas as províncias. 0 país estava às bordas da desintegração e o Terror Branco foi combatido pelo Terror Vermelho (HALLYDA; MOLINEAUX, 1981). A própria hierarquia superior do exército, moldada pela monarquia, foi duramente expurgada. Milícias camponesas foram incorporadas ao novo Exército Vermelho. A Frente de Libertação da Somália Ocidental, da região etnicamente somali de Ogaden, contava com o apoio da Somália, e em abril de 1976 atacou o exército etíope. Tanto os soviéticos, como o próprio Fidel Castro visitaram a Somália, a Etiópia e a Eritréia buscando impedir o conflito entre três nações de regime marxista e propondo uma federação socialista. Mas o nacionalismo falou mais alto e todos rejeitaram a mediação e a proposta. Importante, Cuba não participou das lutas internas nem da repressão ao separatismo eritreu, apenas auxiliou a repelir uma invasão estrangeira, em conformidade com o Direito Internacional e com a posição da União Africana.

Seguiu-se a invasão somali em apoio aos guerrilheiros e à guerra de 197778, na qual os etíopes foram salvos pela ponte aérea de armamentos soviéticos e o envio de 10 mil combatentes cubanos (LEOGRANDE, 1980). Nesse momento, Moscou montou uma ponte aérea, enviando armas, assessores soviéticos e alemães orientais, além de dez mil soldados cubanos. A Somália conquistou toda a região, tomou cidades importantes e ameaçava o acesso ao mar por ferrovia da Etiópia (setembro de 1977 a janeiro de 1978). Entre fevereiro e março de 1978, as tropas cubano-etíopes contra-atacaram e a guerra encerrou-se com a vitória da Etiópia, que consolidou seus laços com o campo socialista, enquanto a Somália aliava-se aos Estados Unidos e às petromonarquias árabes. Do ponto de vista estratégico-militar, foi uma guerra convencional entre dois exércitos

\footnotetext{
${ }^{3}$ O núcleo do Partido Revolucionário do Povo Etíope (PRPE) era formado por estudantes marxistas etíopes formados na Europa, adeptos da "Revolução Já" e o do All-Ethiopia Socialist Movement (Meison) por estudantes também marxistas formados nos EUA. Os segundos eram de uma geração anterior e colaboravam com o novo regime, ao contrário dos mais jovens, radicais, armados e independentes do PRPE.
} 
treinados por países socialistas, no contexto de uma inversão abrupta de alianças, em que o nacionalismo somali foi o catalisador malsucedido.

Mas as guerras contra os eritreus (também marxistas), os somalis e os separatistas ou autonomistas (alguns conservadores e outros marxistas) continuaram consumindo os escassos recursos do país. Apesar dos conselhos soviéticos de implantação de um partido de massas (protelado até a consolidação do regime) e da adoção de uma estrutura federal, Mengistu manteve sua recusa e autonomia. Não foram "peões” da Guerra Fria e a revolução etíope acabou com a sociedade arcaica, de forma muito mais radical do que em Angola (MARKAKIS, WALLER: 1986). Em 1984-5, uma nova seca produziu fome generalizada, com refugiados que o governo retirava das áreas de conflito no Norte e instalava em cooperativas no Sul. Ainda assim, a reforma agrária e a reforma urbana mudaram radicalmente o perfil socioeconômico da nação e a saúde pública teve um significativo desenvolvimento. Mas o mais importante foi a campanha educacional, que alfabetizou a grande maioria da população, recebendo um prêmio da UNESCO (CLAPHAM, 1996).

As dificuldades aumentaram com a chegada de Gorbachov ao poder e com a gradual redução da ajuda soviética. Em 1988-89, o debilitado Exército Vermelho sofreu derrotas na Eritréia e na província do Tigre frente aos insurgentes marxistas (os do Tigre se declaravam "de linha albanesa"). Os dois grupos se associaram numa frente e, com o beneplácito norte-americano, foram autorizados a conquistar o poder, após uma conversão formal ao liberalismo político e econômico. Em 1991, avançaram para a capital e o regime caiu, com a fuga de Mengistu para o Zimbábue (HUGHES, 1992). Em 1993, a Eritreia se tornou independente e, apesar de uma guerra de fronteira entre os dois ex-aliados, as estruturas de poder de ambos pouco mudaram. A Etiópia se tornou uma potência regional e, com apoio chinês, desenvolveu sua economia, deixando de ser o país da fome. Na Somália, frente às dificuldades internas e ao fim da Guerra Fria, Barre deixou o poder em janeiro de 1991. A tentação nacionalista de criar uma "Grande Somália" destruiu o regime e deixou o país dividido entre 14 Senhores da Guerra, mergulhado no terrorismo e sofrendo intervenções internacionais há três décadas. Nenhum regime sucedeu ao socialismo somali (HARPER, 2012). 
Revoluções inesperadas e guerras no mundo islâmico

\section{A Revolução Iraniana e a Guerra com o Iraque}

Com a deterioração da détente e o desencadeamento da Nova Guerra Fria, em fins dos anos 1970, a região cuja instabilidade mais preocupou Washington foi a que o assessor de segurança de Carter, Zbigniew Brzezinski, denominou Arco das Crises. Ela se estende do Chifre da África ao Paquistão, passando pela península arábica. Em função do petróleo do Golfo Pérsico, da proximidade da URSS, dos estreitos e rotas estratégicas do Golfo Pérsico/Árabe e Mar Vermelho e do Oceano Índico, a região era considerada vital para os EUA. Apesar de, no final dos anos 1970, a revolução etíope ainda enfrentar movimentos de guerrilhas, especialmente as eritreias - então apoiadas pelas petromonarquias árabes, pelo Egito de Nasser e pelos EUA -, o Presidente Carter percebia a situação como favorável aos soviéticos, que tinham com a Etiópia uma relação mais efetiva do que ele com a Somália (HALLIDAY, 1982).

A revolução iraniana foi a que mais afetou a estratégia americana na região do Arco das Crises. O Irã possuía o maior, mais bem treinado e equipado exército do Oriente Médio e situava-se estrategicamente entre a fronteira soviética e o Golfo Pérsico. Possuía grande riqueza petrolífera e era o aliado mais importante dos EUA na região, a peça básica de seu esquema militar e o gendarme mais confiável (HALLIDAY, 1981). Entretanto, a oposição à repressiva monarquia do Xá Reza Pahlevi crescia entre os estudantes e parte da classe média, aos quais se associaram os operários do setor petrolífero, liderados pelo Partido Comunista (Tudeh). No início de 1978, os mulás associaram-se à revolta popular, mobilizando as massas mais miseráveis das periferias urbanas, oriundas do êxodo rural. 0 regime perdeu, assim, o controle da situação; a tropa passou para o lado dos revoltosos após semanas de repressão sangrenta e o Xá teve de fugir do país no início de 1979. O Aiatolá Khomeini, recém-chegado do exílio, colocava-se gradativamente no centro do poder.

Nesse sentido, a Revolução Iraniana foi o resultado da convergência de uma luta política contra os vinte e cinco anos de ditadura do Xá, com uma revolta social contra as profundas desigualdades do ambicioso modelo modernizador 
capitalista adotado. Era também uma revolta islâmica e nacionalista contra a cultura ocidental, sobretudo o american way of life. Constituía, enfim, uma reação à abrupta mudança introduzida no país, na esteira da modernização capitalista e contra a sujeição do Irã à diplomacia dos EUA, que no passado havia fomentado o Golpe de Estado que derrubara o governo nacionalista de Mossadegh em 1953 (RODRIGUEZ, 1991).

A frente que derrubou o Xá era integrada por uma ampla gama de tendências, que incluía desde os fundamentalistas xiitas até o influente Tudeh, passando pela burguesia liberal e pelos Mujaedim nacionalistas. Mas as lutas internas conduziram à progressiva hegemonia dos fundamentalistas islâmicos, especialmente com a guerra decorrente da invasão iraquiana em 1980. Assim, a revolução assumia um conteúdo sociopolítico e cultural conservador, autoritário e com algumas práticas obscurantistas. Entretanto, ela implantou um regime republicano semelhante ao gaullismo francês, com direitos políticos plenos para as mulheres e eleições disputadas. Possuía, igualmente, um fortíssimo conteúdo anti-imperialista, que atingiu o paroxismo no episódio dos reféns da embaixada americana em Teerã (ABRAHAMIAN, 2008). O fracasso da tentativa de resgate destes completou a humilhação dos EUA e de seu presidente, que perdeu a reeleição. A Revolução Iraniana desencadeou histeria e pânico no Ocidente e nas petromonarquias absolutistas da península arábica, que imaginava hordas de "fanáticos xiitas" a ameaçá-los, o que foi agravado pelo segundo choque petrolífero.

Como toda revolução, ela adotou um proselitismo militante, de caráter islâmico-xiita anti-saudita e anti-iraquiano, bem como contra "os três satãs": EUA, URSS e Israel. Havia litígios históricos e fronteiriços com o Iraque, agravados pela expulsão para a França do exilado Aiatolá Khomeini em 1975, quando fora celebrado um acordo entre o Regime Baas pan-arabista do Iraque e o Xá. Os iranianos (persas) eram indo-europeus e os iraquianos eram árabes sunitas, mas havia uma população árabe xiita nos dois lados da fronteira sul. Saddam Hussein, o vice-líder que assumira o poder em Bagdá, em 1979, em um golpe palaciano, se afastou da URSS e viu no caos que se seguiu à revolução iraniana a oportunidade de assumir a posição de maior potência regional. Com o 
fuzilamento ou reforma forçada da maioria dos generais e altos oficiais da época do Xá, o imenso exército iraniano se desintegrara e não havia peças de reposição para os armamentos de procedência norte-americana (RAMAZANI, 1988).

A ocasião era tentadora e Saddam invadiu o Irã em 1980, contando com a desorganização do adversário e com uma revolta da população árabe. Mas ela estava mais motivada pela revolução e por sua resgatada dignidade xiita e permaneceram leais. Enfrentando forte resistência e ocupando apenas algumas cidades próximas da fronteira (os portos nas margens do Rio Chatt Al-Arab), em 1981, a frente estava estagnada, com o Irã passando à ofensiva no ano seguinte. Seguiu-se uma guerra de atrito, em que os iranianos (mais numerosos), compensavam sua inferioridade em armamentos com ondas humanas, inclusive de "jovens mártires". Houve escalada com ataques aéreos iraquianos a petroleiros que se dirigiam ao Irã, o qual respondeu com ataques de lanchas rápidas a navios que rumavam para o Iraque, internacionalizando o conflito. Saddam então intensificou ainda mais o conflito, utilizando armas químicas contra rebeldes curdos e tropas iranianas, bem como atacando as cidades do Irã com mísseis, causando destruição e milhares de mortes de civis (RAJAEE, 1993).

A guerra Irã-Iraque foi o mais intenso conflito convencional entre nações do Terceiro Mundo, com elevadíssimo número de mortos e destruição de infraestruturas. Os avanços e recuos, inconclusivos, duraram até 1988, quando foi assinado um armistício, retornando ao status quo ante. A guerra externa foi acompanhada por uma intensa luta pelo poder em Teerã, com as demais forças políticas da revolução sendo derrotadas uma a uma pelos partidários do Aiatolá, culminando com a eliminação dos comunistas em 1983. Quando a guerra acabou, Khomeini estava com câncer e, para evitar que algum dos seus sucessores se voltasse para o Ocidente, obrigou todos a participarem do julgamento que condenou e executou quase todos os presos políticos. A condenação internacional generalizada impediria qualquer líder iraniano de alterar o rumo da revolução e ele faleceu em 1989, com um sentimento de "missão cumprida".

O Iraque, ao longo da guerra, construiu um exército moderno, poderoso, bem armado e treinado, mas ao custo de enorme endividamento externo em relação às petromonarquias, que haviam criado em 1981 o Conselho de 
Cooperação do Golfo 4 , temendo a revolução do Irã. Assim, Saddam considerava que o Iraque havia derramado seu sangue pelos Estados da Península Arábica, os quais também haviam utilizado petróleo iraquiano que ele não conseguia exportar. Portanto, ele acreditava que nada devia; pelo contrário, pediu recursos para a reconstrução, mas isso foi negado e teve a dívida cobrada pelo Kuwait. Após ver a queda do regime romeno, até há pouco cortejado pelo Ocidente (contra a URSS), teria dito: "não serei o próximo Ceaucescu". E invadiu o Kuwait em 1990.

Por que a guerra durou oito longos anos? Há vários elementos a considerar, além da simples determinação de ambos os lados, baseada em rivalidade pessoal, histórica e política. Em primeiro lugar, ela constituiu um elemento de contenção da Revolução Iraniana pelas petromonarquias conservadoras do Golfo e, através delas, dos Estados Unidos e das demais potências capitalistas. Ou seja, a guerra foi uma forma de contrarrevolução internacionalizada. As petromonarquias do Golfo eram prósperas, mas despovoadas e vulneráveis politicamente, pois as massas muçulmanas as viam como subservientes ao Ocidente. Outro ponto é que a continuidade do conflito dividia e enfraquecia o mundo árabe e muçulmano, especialmente debilitando as repúblicas nasseristas e batistas, que eram laicas, socializantes e modernizadoras, até então uma ameaça a Israel.

A deserção do Iraque do campo progressista servia muito bem a Israel que, ironicamente, aproveitou para destruir o reator nuclear iraquiano e forneceu peças de reposição aos iranianos, numa triangulação com os Estados Unidos (o Escândalo Irã-Contras, protagonizado pelo Coronel Oliver North). A Guerra representava, também, o enfraquecimento da diplomacia soviética na região e o Irã se tornava uma ameaça para as repúblicas muçulmanas soviéticas da Ásia Central e Cáucaso, além do aliado Afeganistão, visto adiante. Por fim, fatores econômicos contribuíram para o prolongamento do conflito, com o aquecimento do mercado de armamentos, que fez negócios bilionários, e a manipulação do preço do petróleo. O Japão e os Tigres Asiáticos, por exemplo, compravam petróleo iraniano de forma encoberta e abaixo do preço de mercado.

\footnotetext{
${ }^{4}$ Arábia Saudita, Omã, Emirados Árabes Unidos, Catar, Barein e Kuwait.
} 


\section{A Revolução Afegã e a intervenção soviética}

O bode expiatório da grande virada das relações internacionais foi, no entanto, o Afeganistão, um Estado-tampão formado para separar a expansão dos impérios russo e britânico. O Afeganistão, monárquico, feudal e tribal, sempre teve boas relações com a URSS, e foi o primeiro Estado a reconhecê-la em 1919, mantendo acordos de cooperação econômica e militar desde 1924. Era um país neutro, que propiciava segurança à fronteira soviética, recebendo em troca ajuda econômica, militar, formação de quadros e assistência técnica, sem qualquer interferência na monarquia. Em 1973, em mais um dos golpes de Estado no país, o príncipe Daud depunha seu primo do trono e proclamava a República, apoiando-se em uma ampla frente, da qual fazia parte o grupo marxista Parcham. Houvera certa modernização nos anos 1960, com formação universitária e técnica para milhares de jovens, os quais, contudo, não conseguiam emprego após graduados. Eles percebiam que somente teriam oportunidade se houvesse uma mudança profunda, rompendo com a estrutura sociopolítica de tipo medieval.

A vida política só existia em Cabul e em mais duas ou três cidades e era movida por uma minúscula classe média, a qual muitos oficiais, técnicos e funcionários haviam estudado na URSS. Desses segmentos, além do meio estudantil e da reduzida classe operária, eram oriundos os militantes do Partido Democrático do Povo Afegão (PDPA, fundado em 1965), que se cindira no grupo Parcham - favorável a uma evolução política gradual com a também minúscula burguesia local - e no grupo Khalq, que propunha uma revolução fundada na aliança operário-camponesa. Contudo, a esmagadora maioria do povo do "teto do mundo", dividida em várias etnias, levava uma vida pastoril nômade no campo ou uma vida agrária nas pequenas aldeias. A base principal do Khalk eram os pashtus (etnia majoritária), enquanto a do Parcham eram os tadjiques e usbeques do norte, povos que também constituíam repúblicas federadas na URSS.

O governo Daud, face à crescente desagregação econômica - quase 10\% da população precisava trabalhar no exterior - e à progressiva influência dos comunistas no governo, começou a aceitar a ajuda econômica do Xá do Irã, que desejava criar sua própria área de influência. Desde 1974, Daud permitiu a atuação 
da Savak (polícia política iraniana) dentro do governo afegão, para eliminar a esquerda do aparelho estatal. A situação agravou-se quando Cabul resolveu reorientar sua diplomacia, aproximando-se também de China, EUA e Paquistão. Neste contexto, o Parcham e o Khalq reunificaram-se, enquanto as crescentes manifestações de rua levaram Daud a efetuar prisões em massa e assassinar líderes comunistas. Assim, em abril de 1978, o PDPA, com apoio de outros grupos políticos, reagiu apressadamente desfechando um golpe de Estado, que denominou "Revolução de Abril (ou Saur)". Tratou-se, basicamente, de um golpe militar bastante improvisado, desfechado por oficiais de média patente, vinculados ao PDPA (especialmente Khalk), para evitarem ser presos (e mortos) pelo governo. Outro ponto importante é que a historiografia rigorosamente acadêmica, não mais influenciada pela Guerra Fria e na posse de arquivos agora disponíveis em Moscou, tem demonstrado que não houve interferência soviética no golpe (HALLIDAY, 1982) .

O novo governo era liderado por Taraki, do Khalq, que iniciou programas de alfabetização, reforma agrária, emancipação dos jovens e das mulheres e nacionalização de alguns setores da economia. Não obstante, a luta interna prosseguia, e Hafizullah Amin - também do Khalq - isolou progressivamente Taraki e o grupo Parcham. Amin então acelerou perigosamente a "revolução pelo alto", ao que se somaram os excessos do regime, desencadeando uma autêntica revolta rural contra as reformas, desde maio de 1979. A família patriarcal recusava-se a abrir mão do controle sobre as mulheres e do trabalho dos jovens, e o clero reagia contra a reforma agrária. Centenas de professores de escolas de alfabetização, enviados pelo governo ao interior, bem como mulheres que iam às aulas, foram assassinados. Logo a revolta tribal passava a receber apoio externo via Paquistão, escapando ao controle do governo (BRADSHER, 2002)

Os soviéticos, já preocupados com os primeiros ventos da Nova Guerra Fria, resolveram então agir. À Revolução Iraniana, com seu proselitismo religioso, somava-se o Paquistão, cujo regime recém-islamizado, focava na Ásia central

\footnotetext{
A decisão dos golpistas foi tomada poucas horas antes, em meio à onda de prisões desencadeada por Daud. O sigilo e a rapidez foram determinantes para o sucesso do movimento e o Embaixador soviético teria sido apenas alertado, recebendo instruções para não se envolver e aguardar os acontecimentos.
} 
soviética e no Afeganistão. Havia, ainda, a crise da Polônia (mais a eleição de um Papa polonês), o conflito do Vietnã contra a China e a guinada da administração Carter, que constituíam objeto de preocupação para o Kremlin. Taraki foi a Moscou negociar a deposição do odiado Amin, que percebeu a manobra e assassinou-o assim que retornou a Cabul. Os soviéticos não poderiam cortar a ajuda ao país, mas como disse André Fontaine (1982), haviam sido "desafiados por um mosquito de terceira categoria, e isso é algo que não se perdoa". O Kremlin não poderia recuar no país, pois o conflito adquirira nova dimensão com o triunfo da Revolução Iraniana e o grande fluxo de armas e dinheiro para a guerrilha islâmica afegã, oriundo dos EUA, China, Paquistão, Egito e Arábia Saudita. Assim, a URSS resolveu apoiar um golpe para derrubar Amin, a ser complementado com a intervenção militar maciça para apoiar o novo governo, o que veio a ocorrer em 27 de dezembro de 1979 (LEVÉSQUE, 1990).

A decisão da intervenção foi difícil, como demonstram as atas das reuniões da cúpula soviética, em que todos pesavam o que seria menos danoso: intervir ou não? A votação favorável foi apertada, mas ninguém, militares ou civis, era entusiasta e todos sabiam que os custos seriam altos. Todavia, apesar da suposta "surpresa" Ocidental, documentos já desclassificados informam que a administração Carter apostava nessa possibilidade, como forma de atrair o urso soviético para fora da toca: “ótimo, agora eles terão o seu Vietnã”, teria sido declarado em Washington. Os acordos com o Paquistão e o fornecimento de armas, através desses, aos insurgentes afegãos eram já de conhecimento geral. As narrativas de um plano geopolítico expansionista soviético para ameaçar as rotas de petróleo não foram demonstradas pela nova documentação disponível, pois o objetivo básico era evitar a queda do regime afegão. Esse novo governo era liderado por Brabak Karmal, do Parcham, que promoveu uma abertura política, moderou o ritmo das reformas e buscou uma aproximação com os líderes religiosos e chefes tribais, enquanto os soviéticos tentavam reerguer o Estado e o exército afegãos, e suas tropas procuravam controlar os pontos vitais do país. Era tarde, porém: as bases guerrilheiras encontravam-se instaladas no Paquistão, e era impossível controlar a infiltração pelas altas montanhas (GUPTA,1987). 
A guerra se concentrou em repelir ataques no eixo rodoviário e anel urbano que contornava as montanhas mais altas e em ofensivas irregulares em alguns vales estratégicos onde as guerrilhas se organizavam. O efetivo máximo soviético chegou a 100 mil soldados (no Vietnã foram 600 mil americanos), apoiados por um exército afegão equivalente e milícias de apoiadores do regime ou chefes locais pagos por ele. A brutalidade dos guerrilheiros afegãos e dos "voluntários árabes" (como Bin Laden), que decapitavam os prisioneiros, foi respondida com bombardeios soviéticos para despovoar regiões em que a guerrilha se refugiava. O regime e seus apoiadores soviéticos controlavam as cidades e o "Afeganistão útil" e seu anel rodoviário, com as guerrilhas se concentrando em regiões de mais difícil acesso. Com a chegada de Gorbachev ao poder, a política soviética começou a mudar e a buscar um desengajamento. Isso se devia em parte aos custos econômicos da intervenção, mas muito mais em favorecer um entendimento com os EUA, bem como vencer seus adversários em Moscou, que apoiavam Karmal, pois no campo de batalha a situação era equilibrada. Se o governo não conseguia controlar o campo, os sete grupos guerrilheiros (que muitas vezes lutavam entre si) não conseguiam se unir nem conquistar qualquer posição importante permanentemente. O Paquistão, pensando em seus próprios interesses no Afeganistão, e no tráfico de heroína (com a conivência da CIA), tinham seus próprios preferidos (DORRONSORO, 2005).

Assim, sob pressão soviética, o dirigente do Khad (polícia política), o Dr. Najibullah (um médico Khalk moderado), ascendeu ao poder em 1986. O novo governo visou consolidar certas reformas e começar a negociação com os mujahidins, desistindo da ênfase em ofensivas militares. Nessa época, além de contar com cada vez menos ajuda soviética, o regime viu-se em estado de isolamento interno, uma vez que os Khalqis e os apoiadores de Karmal formaram uma forte oposição. Seu governo também foi marcado pela Política de Reconciliação Nacional, alinhada com as políticas de Gorbachev. Mas os reformadores de Moscou sabotavam as iniciativas militares, como forma de preparar a retirada, em troca da manutenção da ajuda em armas e dinheiro. 0 regime, por sua vez, buscava desfazer-se de alguns símbolos socialistas e aparentar uma linha patriótica (quando os soviéticos se retiraram, o Partido foi 
rebatizado Watan, ou Pátria). Com as negociações de Genebra, começou a retirada da URSS do Afeganistão e, com a saída concluída em fevereiro de 1989, os guerrilheiros partiram para a ofensiva, mas o cerco à cidade de Jalalabad foi derrotado pelo regime (CORDOVEZ; HARRISON, 1995).

Surpreendentemente, o regime socialista afegão sobreviveu à saída dos soviéticos, à progressiva redução da ajuda econômica e militar, ao fim da Guerra Fria e, por um tempo, à própria desintegração da URSS. As ofensivas guerrilheiras, fortalecidas pela continuidade da ajuda externa, não conseguiram derrubar o governo, nem chegar a um acordo para a formação de um novo regime. Cabul se transformara numa cidade-estado, onde refugiados do campo e segmentos urbanos apoiavam o governo, particularmente as mulheres. Com a desintegração da URSS nos meses finais de 1991, a ajuda foi completamente cortada. Ainda assim, o regime socialista resistiu até abril de 1992, quando a deserção de Rashid Douston, chefe da milícia uzbeque, causou o colapso do regime. No Afeganistão socialista, mulheres ocupavam cargos de poder, e com a queda do regime foram impedidas de estudar e de trabalhar, tendo orelhas e nariz cortados quando desobedeciam. O Afeganistão foi para o socialismo o que fora a Vendéia para a Revolução Francesa: o local onde a classe mais desfavorecida lutou contra as políticas de sua libertação.

Os vencedores não se puseram de acordo, e a guerra civil prosseguiu. Cabul, ocupada por diferentes milícias, até então intacta foi praticamente destruída, com $70 \%$ da população fugindo para o campo. Os remanescentes do regime derrubado juntaram-se a diferentes grupos, que tenderam a se agrupar por etnias. Estes, por sua vez, recebiam apoio externo de potências regionais, desejosas de ocupar o vácuo de poder provocado pela fragmentação da URSS. Refugiado por quatro anos na representação da ONU em Cabul, ao sair do prédio em 1996, Najibullah e seu irmão foram castrados, empalados em praça pública e tiveram seus corpos retalhados. A contrarrevolução daqueles que Reagan denominou de "Paladinos da Liberdade" gerou o regime ultra-obscurantista dos talibãs. Ele albergou a Al-Qaeda, que atacaria Nova Iorque e Washington em 11 de setembro de 2001. 
Guerras e Revoluções na Indochina: impactos regionais e sistêmicos

\section{A Revolução Vietnamita e as Guerras Indochinesas}

Na Indochina, o Vietnã travou, desde os anos 1940 um conjunto de guerras em que japoneses, franceses, norte-americanos e chineses tiveram de abandonar o território vietnamita, derrotados. Ao mesmo tempo, esse conjunto de guerras constituiu uma revolução que permitiu a implantação de regimes socialistas, que ainda permanecem no poder no século XXI. Portanto, não se trata apenas de vitórias militares, mas de transformações sociais (VISENTINI, 2007). Após a capitulação japonesa, a obtusa política colonial francesa encontrou forte resistência do movimento Viet-Minh, liderado por Ho Chi Minh. A tentativa de recolonizar o país, revertendo a independência da República Democrática do Vietnã (proclamada em 1945), conduziu a uma longa guerra, que se aprofundou com a chegada dos comunistas ao poder na China em 1949. Após oito anos de luta, a guerrilha vietnamita, liderada por Giap, infligiu uma derrota final ao exército francês em Dien Bien Phu. A França viu-se obrigada a repassar as responsabilidades da guerra aos EUA e a assinar os acordos de Genebra em 1954, que dividiam temporariamente o Vietnã (mantendo o regime comunista no Norte) até a realização de eleições, previstas para dois anos depois.

Os EUA haviam tentado evitar uma vitória comunista no Vietnã, após a derrota de seus aliados na China e o empate na Guerra da Coreia ("a primeira guerra que não vencemos", segundo o militar americano que assinou o cessarfogo (HOROWITZ, 1973, p.86)). Para reforçar sua posição na região, aumentaram a ajuda militar a Saigon. Logo, a monarquia viria a ser derrubada no Sul por um golpe apoiado pela CIA, e o novo regime nunca realizou as prometidas eleições. Assim, no fim dos anos 1950, a guerrilha reapareceria no Sul e se espraiaria para o Laos e o Camboja, com o crescente envolvimento direto dos Estados Unidos. O Camboja e o Laos obtiveram a independência na Conferência de Genebra, transformando-se em monarquias neutralistas. O primeiro manteve sua estabilidade até os anos 1960, sob a liderança do carismático Príncipe Sihanuk, mas o Laos, já nos anos 1950, foi envolvido no conflito vietnamita, devido à utilização do seu território pelo exército do Vietnã do Norte e pelos guerrilheiros Vietcongs do sul. 
No mesmo ano da Conferência de Genebra (1954), realizou-se a Conferência de Colombo, na qual Índia, Paquistão, Indonésia, Birmânia e Ceilão (Sri Lanka) discutiram a articulação de uma frente neutralista, devido ao problema da Indochina. Os EUA substituíam a metrópole francesa e criavam mais um bloco militar, a OTASE6 . Esse bloco militar, através do Paquistão, EUA e GrãBretanha, se ligava a outro no Oriente Médio, a CENTO (Organização do Tratado do Centro), e através desse, com a OTAN na Europa. Agregando-se a estes os pactos militares bilaterais dos EUA na Ásia oriental (Japão, Coreia do Sul, Taiwan e Filipinas), obtinha-se uma linha de contenção do campo socialista, o qual se estendia de Berlim ao Oceano Pacífico, englobando um terço das terras e da população mundial (WESTAD, 2007).

Apesar do fracasso francês em recolonizar o Vietnã e das dificuldades militares enfrentadas naquela oportunidade, os EUA tomaram a decisão política de intervir na região, devido à debilidade do regime sul-vietnamita e ao avanço do Vietnã do Norte e do Vietcong no Sul. A criativa luta de guerrilhas vietnamita provocou um imenso desgaste aos Estados Unidos, embora a um custo humano e ambiental impressionante para um pequeno país. A Guerra não poderia ser vencida por Washington, nem o regime socialista do Norte derrotado. Neste contexto, Nixon e Kissinger procuravam reduzir os gastos e o envolvimento militar dos EUA, bem como encontrar uma saída diplomaticamente honrosa e geopoliticamente aceitável para a Guerra do Vietnã. As perdas americanas eram imensas e os efeitos disso já atingiam a política interna norte-americana. A Ofensiva Tet (Ano Novo Lunar), em 1968, evidenciou a vulnerabilidade do exército americano, quando suas tropas foram atacadas em todo o país em operações simultâneas. A superpotência, assim, enfrentava uma crise de credibilidade e, também, consumia seus recursos financeiros.

No ano de 1969, essa situação levou o presidente norte-americano a formular a Doutrina de Guam (vietnamização do conflito e desengajamento americano) e a promover a aproximação sino-americana, por meio da chamada Diplomacia do Ping-Pong em 1971. Em decorrência das negociações, a China

\footnotetext{
6 Organização do Tratado da Ásia do Sudeste, que agrupava Austrália, Nova Zelândia, GrãBretanha, França, Filipinas, Tailândia, Paquistão e os próprios EUA.
} 
Popular ingressava na ONU, ocupando o lugar de Taiwan no Conselho de Segurança como membro permanente e logrando, assim, legitimar-se e inserirse no concerto das nações. Em seguida, Nixon visitou a capital chinesa, celebrando uma aliança voltada primordialmente para a contenção do vietnã do Norte e contra a URSS e os movimentos revolucionários do Terceiro Mundo. A aproximação sino-americana, além disso, foi possibilitada pelo progressivo afastamento entre Moscou e Pequim, o que abriu espaço para essas negociações (LOI, 2006).

Neste quadro, enquanto o apoio chinês ao Vietnã do Norte diminuía, Hanói buscava maior cooperação com a URSS, e a derrota americana no Vietnã, no Camboja e no Laos não pôde ser evitada. Em abril de 1975, os vietconge as tropas do Norte derrotaram o regime de Saigon e, em 1976, os dois Vietnãs se unificaram, tornando-se a República Socialista do Vietnã. Chegava ao fim um conflito devastador, em que a maior potência do planeta (com 600 soldados no país) foi derrotada por uma guerra popular, de forte impacto internacional. Mas o devastado Vietnã não teria tempo de comemorar, não apenas pela penosa reconstrução necessária, mas pelos novos desafios que se avizinhavam (BERESFORD, 1986).

O reforço da posição soviética em relação à Índia e ao Vietnã era percebido pela China como um cerco (a URSS também protegia a Mongólia socialista desde os anos 1920), e as relações sino-vietnamitas foram conhecendo um progressivo esfriamento. Desde 1976, a China passou a apoiar o regime de Pol Pot no Kampuchea, que atacava frequentemente o Vietnã no sul. A tragédia do Kampuchea (a nova denominação do Camboja) tem início logo após a conquista de Pnom Penh pelos Khmer Vermelhos, que fundaram a República Democrática do Kampuchea. Em 1975, o príncipe Sihanuk assumiu a presidência e Penn Nouth foi nomeado primeiro-ministro, mas o verdadeiro poder encontrava-se nas mãos de Pol Pot e leng Sary. Eram dois intelectuais comunistas vindos do exílio parisiense e fortemente influenciados pelo Maio de 1968 e pela Revolução Cultural maoísta. As primeiras medidas do novo regime foram a eliminação física dos membros do derrubado governo Lon Nol (militar pró-EUA) e das classes dominantes, a transferência em massa de população urbana para o campo 
(Pnom Penh desce de 2,5 milhões de habitantes para 700 mil em poucos meses) e o isolamento quase completo do país com relação ao exterior.

Quase todas as embaixadas são fechadas, e mesmo o pessoal diplomático de países amigos sofre uma severa reclusão. Em pouco tempo, a única embaixada no país é a da China, sendo este o vínculo exclusivo com o estrangeiro. Logo Sihanuk é derrubado e confinado em prisão domiciliar, enquanto Pol Pot e leng Sary assumem o controle direto do Estado. Os monges budistas, intelectuais e outros grupos aliados na luta contra Lon Nol começam a ser perseguidos. A moeda é eliminada, a xenofobia cresce, toda influência externa é perseguida e ocorre a eliminação das minorias étnicas (170 mil vietnamitas fogem do país). O passado khmer passa a ser glorificado, bem como a volta à idealizada "idade de ouro" do Império de Angkor. O PC do Kampuchea começa a ser chamado simplesmente de Angka. A produção agrícola aumenta, mas a maior parte do arroz é exportada para a China, que envia armas e elogia o regime. A vida social é destruída, com 750 mil pessoas (20\% da população) sendo assassinada, morta de fome e de doenças no campo, e outros 30\% se refugiam na Tailândia ou no Vietnã. Há tentativas de rebelião de camponeses e, também, de setores do Exército e do partido. Contudo, são esmagadas, o que leva a novos expurgos de todos os suspeitos de "simpatia pelo Vietnã". Os ataques às fronteiras vietnamitas, neste contexto, são intensificados (VICKERY, 1987)

Como foi possível tal fenômeno de regressão social? Historicamente, as revoluções que se apoiaram no socialismo de viés marxista procuraram industrializar e desenvolver a sociedade, situando a idade de ouro da humanidade no futuro, seguindo a tradição racional-iluminista. No Camboja, o populismo do príncipe Sihanuk havia criado a ideologia do "socialismo budista khmer", como forma de arregimentar apoio do campesinato tradicional. Esse grupo estava ameaçado pelo avanço do capitalismo no país, percebido como a "exploração do campo pela cidade", o que feria seu universo patriarcal e igualitarista.

Hu Yong, Hu Nim e Khieu Samphan, os ideólogos do partido comunista, consideraram essa camada retrógrada como a principal força revolucionária do país e reelaboraram o igualitarismo camponês voltado à idade de ouro patriarcal, a partir de posições ultra-esquerdistas, sobretudo maoístas. Defendiam a 
eliminação das cidades e a organização do país em uma comunidade de cooperativas com uma economia natural e sociedade militarizada, que restauraria o esplendor da civilização khmer do Império de Angkor. Do Vietnã, exigiam a devolução das regiões que haviam pertencido ao Império um milênio antes! Paralelamente ao auge dos incidentes de fronteira, o Vietnã promove uma reforma monetária que fere os interesses do grande e médio comércio, a maioria do qual nas mãos dos hoa, de origem chinesa, que sabotavam o Plano Quinquenal e comprometiam o abastecimento. A China aproveita a ocasião para interromper a ajuda e cortar relações com Hanói, acusando-a de opressão aos hoa.

No início de dezembro de 1978, foi fundada a Frente de Unidade Nacional do Kampuchea para a Salvação Nacional (FUNKSN), congregando a resistência que atuava contra o regime de Pol Pot em 16 das 19 províncias no país. A FUNKSN era liderada por Heng Samrin, um general Khmer que se rebelara contra o regime, refugiando-se depois no Vietnã, o qual apoiou a criação da Frente. Com a intensificação dos ataques à fronteira vietnamita, Hanói resolveu revidar e entrou no país com mais de 100 mil soldados, apoiados pelas unidades da FUNKSN. Em 7 de janeiro de 1979, Pnom Penh foi libertada e dia 11 fundou-se a República Popular do Kampuchea. As tropas do regime de Pol Pot fogem para a fronteira da Tailândia, enquanto o novo governo denunciou as atrocidades e abriu o país à imprensa internacional.

Como resposta, os chineses cruzam a fronteira norte-vietnamita em fevereiro de 1979 para "dar uma lição ao Vietnã", segundo Deng Xiaoping declara a Carter. Quatro províncias fronteiriças são arrasadas por um exército de 600 mil chineses. A União Soviética informa a China que honraria seu tratado com o Vietnã caso a guerra prosseguisse. Em março, o Exército chinês retira-se humilhado (com 60 mil baixas), com o Vietnã demonstrando sua capacidade militar, mas tendo que defender o Norte dos chineses e se manter no Kampuchea, ao Sul. Tinham que ajudar o novo governo a reconstruir o país e enfrentando os ataques do Khmer Vermelho, agora apoiado pela Tailândia, China e Estados Unidos, numa guerra que exauriu suas forças e consumiu recursos soviéticos (REPÚBLICA POPULAR DE KAMPUCHEA, 1985). O Vietnã vencera mais uma potência. Como as relações entre dois países socialistas puderam chegar a 
uma guerra total? A China justificava sua invasão como resposta a uma tentativa do Vietnã de dominar a Indochina. Na verdade, a perspectiva chinesa preocupava-se com a força autônoma da Revolução Vietnamita, numa região que fora historicamente periferia do império chinês, e pelo fato dessa revolução buscar o apoio soviético para manter sua independência face ao poderoso vizinho (MORENO; MANDEL, 1979). Obviamente que problemas milenares influenciavam a relação entre as duas nações. Mas o principal era a orientação pró-ocidental da política externa chinesa desde o declínio da Revolução Cultural. A aproximação com os Estados Unidos a partir de 1971 (a Diplomacia do Ping-Pong), atingia o ponto culminante na investida contra os comunistas vietnamitas.

A normalização no Camboja foi a mais difícil de obter. Com o advento da Perestroika e a retirada das tropas vietnamitas (estimadas em 100 mil soldados), o dirigente pró-vietnamita Heng Samrin foi substituído por Hun Sen. Em 1989, o toque de recolher foi suspenso, pequenas reformas econômicas liberalizantes foram introduzidas e a denominação da República Popular do Kampuchea foi mudada para Estado do Camboja. Contudo, apesar da retirada das forças vietnamitas, as forças governamentais conseguiram deter a ofensiva do Khmer Vermelho e fazer seus guerrilheiros recuarem para a fronteira da Tailândia em 1990. Em 1992, foi assinada a paz e Hun Sen, o aliado comunista dos vietnamitas, venceu as eleições e segue no poder até hoje como Primeiro Ministro, em uma nação teoricamente monárquica. Ironias da História.

Assim como no caso de Angola, Etiópia, Irã e Afeganistão, o Vietnã e o Kampuchea reuniram guerra e revolução em movimentos associados. Embora as origens de todos esses conflitos repousassem em fatores locais, elas representaram o zênite da projeção militar e geopolítica para Moscou. Mas também constituíam um fardo insuportável para a URSS ${ }^{7}$, que entrou em colapso logo em seguida. A eclosão das revoluções trouxera vantagens estratégicas inesperadas para o Kremlin, mas as guerras que se seguiram, não, e ao mesmo tempo ele não poderia se desengajar dos mesmos. As "Guerras Quentes" derreteram a Guerra Fria e o "socialismo que veio do frio".

\footnotetext{
Além desses, o Kremlin tinha de subsidiar Cuba, Nicarágua, lêmen do Sul, Moçambique, Laos e Coreia do Norte (VISENTINI, PEREIRA, MARTINS, RIBEIRO, GROHMANN: 2013)
} 


\section{Referências}

ABRAHAMIAN, Ervand. A history of modern Iran. Cambridge: Cambridge University Press, 2008.

ANSARI, Ali. Confronting Iran. New Delhi: Foundation Books, 2006.

BERESFORD, Melanie. Vietnam: politics, economics and society. London: Pinter Publishers, 1986. (Marxist Regimes).

BRADSHER, Henry. Afghan communism and Soviet intervention. Oxford: Oxford University Press, 2002.

BREHONY, Noel. Yemen divided. London: I. B. Tauris, 2011.

CABRAL, Amílcar. A arma da teoria. Rio de Janeiro: Codecri, 1980.

CHABAL, Patrick (ed.). A history of postcolonial lusophone África. London: C. Hurst \& Co., 2002.

CHALIAND, Gerard. A luta pela África: estratégia das potências. São Paulo; Brasiliense, 1982.

CLAPHAM, Christopher. Africa and the international system: the politics of state survival. Cambridge: Cambridge University Press, 1996.

COKER, Christopher. NATO, The Warsaw Pact and Africa. New York: St. Martin's Press, 1985.

CORDOVEZ, Diego; HARRISON, Selig. Out of Afghanistan: the inside story of the soviet withdrawal. Oxford: Oxford University Press, 1995.

DAVIDSON, Basil. A política da luta armada: libertação nacional nas colónias africanas de Portugal. Lisboa: Caminho, 1979.

DAVIES, J. E. Construtive Engagement?: Chester Crocker \& American policy in South Africa, Namíbia and Angola. Oxford: James Curry, 2007.

DAVIS, Mike. O imperialismo nuclear e dissuasão extensive. In: THOMPSON, Edward et al. Exterminismo e Guerra Fria. São Paulo: Brasiliense, 1985.

DEUTSCHER, Isaac. Marxismo, guerras e revoluções. São Paulo: Ática, 1991.

DORRONSORO, Gilles. Revolution unending: Afghenistan: 1979 to the present. London: Hurst \& Company, 2005. 
GOLDSTONE, Jack; GURR, Robert; MOSHIRI, Farrok (ed.). Revolutions of the late Twentieth Century. Boulder: Westview, 1991.

GUPTA, Bhabani. Afghanistan: politics, economics and society. London: Pinter Publishers, 1987. (Marxist Regimes)

GEORGE, Edward. The Cuban intervention in Angola, 1965-1991. London: Frank Cass, 2005.

HAGHIGHAT, Chapour. Iran, la révolution islamique. Bruxelles: Editions Complexe, 1985.

HALLIDAY, Fred. Repensando as relações internacionais. Porto Alegre: Ed. da Universidade UFRGS, 2007.

HALLIDAY, Fred. L’URSS et le monde Árabe. Paris: Le Sycomore, 1982.

HALLIDAY, Fred. Iran, dictadura y desarrollo. México. Fondo de Cultura Econômica, 1981.

HALLIDAY, Fred. Revolution and world politics: the rise and fall of the sixth great power. Durham: Duke University Press, 1999.

HALLIDAY, Fred. Génesis de la segunda Guerra Fria. Mexico: Fondo de Cultura Econômica, 1983.

HALLIDAY, Fred. Cold War, third world. London: Hutchinson Radius, 1989.

HALLIDAY, Fred; MOLYNEUX, Maxine. The Ethiopian revolution. London: Verso: NLB, 1981.

HOROWITZ, David. From Yalta to Vietnam. Paris: Unión Génerale d'Éditions, 1973. v. 1.

HUGHES, Arnold (ed.). Marxism's retreat from Africa. London: Frank Cass, 1992. (The Journal of Communism Studies).

KALDOR, Mary. New \& old wars: organized violence in a global era. Cambridge: Polity Press, 1998.

LEOGRANDE, William. Cuba's Policy in Africa, 1959-1980. Berkeley: Institute of International Studies, University of California, 1980.

LOI, Luu Van. Fifty years of Vietnamese Diplomacy (1945-1995). Ha Noi: The Gio'l Publishers, 2006. 
MARKAKIS, John; WALLER, Michael. Military marxist regimes in Africa. London: Frank Cass, 1986.

MORENO, Nahuel; MANDEL, Ernest. China x Vietnã. São Paulo: Editora Versus, 1979.

REPUBLICA SOCIALISTA DE VIET NAM. Ministerio de las Relaciones Exteriores. Las relaciones entre Viet Nam y China 1949-1979. La Habana: Editorial de Ciencias Sociales, 1979.

OTTAWAY, Marina. Soviet and American influence in the Horn of Africa. New York: Praeger, 1982.

RAMAZANI, R. K. Challenge and response in the Middle East. Baltimore: The Johns Hopkins University Press, 1988.

RAJAEE, Farhang (ed.). The Iran-Iraq war. Gainesville: University Press of Florida,1993.

REPÚBLICA POPULAR DE KAMPUCHEA. Ministerio de Assuntos Exteriores. La guerra no declarada contra la Republica Popular de Kampuchea. Pnom Penh: Departamento de Prensa, 1985.

RICHARDS, Michael D. Revolutions in World History. Nova York: Routledge, 2004.

SCHUTZ, Barry, and SLATER, Robert (ed.). Revolution and political change in the Third World. Boulder: Lynne Rienner; London: Adamantine, 1990.

SCHWAB, Peter. Ethiopia: politics, economics and society. London: Francis Pinter, 1985. (Marxist Regimes).

SHUBIN, Vladimir. The hot "cold war": the USSR in Southern Africa. London:

Pluto Press; Scottsville: University of KwaZulu-Natal Press, 2008.

SILVA, Francisco Carlos Teixeira da (org.). Enciclopédia de guerras e revoluções do Século XX. Rio de Janeiro: Elsevier, 2004.

SKOCPOL, Theda. States and social revolutions. Cambridge: Cambridge University Press, 1979.

SOMERVILLE, Keith. Southern Africa and the Soviet Union. London: Macmillan, 1993.

SOMERVILLE, Keith. Angola: politics, economics and society. London/New York: Pinter Publishers, 1989. (Marxist Regimes). 
TURNER, John W. Continent ablaze: the insurgency wars in Africa, 1960 to the present. Johannesburg: Jonathan Ball Publishers, 1998.

VICKERY, Michael. Kampuchea: politics, economics and society. London: Pinter Publishers, 1987. (Marxist Regimes).

VISENTINI, Paulo F. Revoluções Africanas: Angola, Etiópia e Moçambique. São Paulo: Ed. UNESP, 2012.

VISENTINI, Paulo F. A Revolução Vietnamita. São Paulo: Ed. UNESP, 2007.

VISENTINI, Paulo; PEREIRA, Analúcia D.; MARTINS, José M.; RIBEIRO, Luis D.; GRÖHMANN, Luis G. Revoluções e regimes marxistas: rupturas, experiências e impacto internacional. Porto Alegre: Leitura XXI: NERINT-UFRGS, 2013.

WESTAD, Odd Arne. The global Cold War. Cambridge: Cambridge University Press, 2007. 